\title{
Selected aspects of advance care planning according to Polish legal regulations - physician's requirements
}

\begin{abstract}
In 2017, the group of 109 experts from various countries developed the international consensus definition of advance care planning (ACP), which is defined as enabling individuals to define objectives and preferences for future medical treatment and care, to discuss these goals and preferences with family and healthcare providers, and to record and review these preferences if appropriate. ACP plays a significant role in the care of patients with chronic diseases, and especially may have an impact on the situation of palliative care patients, their families and healthcare professionals who look after them.

This article analyses the legal constraints of ACP in Poland, and presents legal regulations related to some selected issues of ACP. One of the essential features of ACP is disclosing information to the patient and taking into account the patient's decisions concerning the treatment and medical care. This is provided for in Polish law and healthcare professionals are obliged to observe it. Moreover, the Polish law includes broad principles applying to providing the patient's family with information about diagnosis and prognosis of the disease. However, advance directives and health care proxy have not been regulated by national law yet. Therefore, it seems that the incorporation of ACP into Polish healthcare system requires the development of new legal regulations.
\end{abstract}

Key words: advance care planning, legislation and jurisprudence, informed consent, Poland

Palliat Med Pract 2019; 13, 4: 197-203

\section{Introduction}

In September 2017, The Lancet Oncology journal published the results of the work of the international team of experts of the European Association for Palliative Care (EAPC) [1]. Based on the opinion of 109 professionals from Europe, North America and Australia, using the Delphi method, a consensus was reached on advance care planning (ACP). In accordance with the position of the EAPC experts, a definition has been established whereby the advance care planning allows people with the ability to make informed decisions:
1. To identify their values.

2. To consider the significance and consequences of the possible course of a serious disease.

3. To define objectives and preferences for future medical treatment and care.

4. To discuss the above issues with family and health care providers.

ACP refers to the physical, mental, social and spiritual realms of the person, encourages the appointment of a personal health care proxy, the registration and regular verification of all declarations of intent so that preferences can be taken into account if the person is unable to make decisions in the future [1].

Address for correspondence:

Leszek Pawłowski

Department of Palliative Medicine, Medical University of Gdańsk

e-mail: Ipawlowski@gumed.edu.pl

Palliative Medicine in Practice 2019; 13, 4, 197-203

Copyright (C) Via Medica, ISSN 2545-0425

DOI: 10.5603/PMPI.2019.0023 
The methods of conduct in ACP are not commonly used in Polish medical practice, and the number of scientific publications on this issue in Poland is limited. So far, there has been no uniform nomenclature in the Polish language for this type of treatment of patients. In the available Polish literature, ACP is interpreted as planning the end-of-life care for the future, planning end-of-life care together with the patient, or planning care in advance. The term ACP is also understood as the written will expressed by the patient concerning medical procedures in advanced stages of the disease, or only care or treatment planning [2-6]. In the light of the EAPC definition, ACP goes beyond the scope of end-of-life care or treatment planning, and is not limited to the expression of the patient's will, as it also includes the provision of information to the patient and family members. In this article, the concept of advance care planning has been interpreted as "planning care in advance", which, in our opinion, corresponds most closely to the definition developed by the EAPC team of experts [1]. In the legal sense, advance care planning is generally considered in relation to the following issues:

1. Advance directives made by patients in the event of a loss of the ability to make decisions concerning future care and medical treatment.

2. Appointment by the patient of a health care proxy in the event of the circumstances mentioned in the previous point.

3. Legal regulations concerning the communication with the patient and his or her family concerning the determination of intent and preferences for future care, as well as legal regulations regarding the treatment of the patient on the basis of previously expressed will [7].

\section{Advance directives}

In Poland, no legal regulations have been adopted so far to define the criteria for applying "forward-looking" pro futuro statements in medical practice. This does not mean that such statements, previously made by the patient, have no legal effect [8-10]. According to the provisions of law, the lapse of time does not constitute a circumstance which results in the invalidity or loss of effectiveness of the patient's declaration regarding the acceptance or objection to the provision of health services. Among others, the Supreme Court spoke in favour of the binding character of such statements. In the light of the reasons given for the ruling of 27 October 2005 (III CK $155 / 05)$, the physician should take into account the patient's prior statements concerning future medical treatment if they are made in a clear, unambiguous manner and do not give rise to any other doubts. In practice, however, the assessment of the effectiveness of such claims may result in difficulties related to the lack of specific legal provisions laying down the rules for their application [11]. Apart from establishing provisions concerning pro futuro statements, it seems advisable to introduce into the Polish law the solutions determining the limits of medical therapies, such as the definition of overzealous therapy, established by the Polish Working Group on End-of-Life Ethics. The definition specifies the conditions of discontinuation of procedure and treatment, which may prolong the period of dying, expose the patient to unnecessary suffering and violate the dignity of the patient [12].

\section{Health care proxy}

In Poland, there is no possibility for the patient to appoint a person who will be able to make decisions concerning medical procedures on behalf of the patient. Pursuant to the Civil Code regulations, an attorney may be appointed for the performance of legal activities on behalf of the represented person, but he or she is not entitled to make declarations of acceptance or objection regarding the provision of health services to the patient. Such statements, in accordance with the opinions prevailing in the doctrine, are not declarations of intent within the meaning of civil law. An attorney acting on the basis of the Civil Code provisions has not been included in the closed catalogue of persons authorised to give consent to the provision of health services. It should be noted that apart from the patient himself or herself, a closed group of entitled persons includes his or her statutory representative, the guardianship court and, to a limited extent, a de facto carer [13].

The Polish Working Group on End-of-Life Ethics prepared the proposal of legal solutions in this respect, which postulates the introduction of the institution of a health care proxy, appointed by the patient, together with the scope of his or her competences [14]. The proposed solution is not a type of power of attorney provided for in the Civil Code, but a completely new form of patient representation. Its implementation into Polish law would require amendments to the provisions of the Act of 6 November 2008 on Patient Rights and the Patient Rights Ombudsman (Journal of Laws [Dz. U.] of 2017, item 1318, as amended) and the Act of 5 December 1996 on Professions of Doctor and Dentist (Journal of Laws [Dz. U.] of 2018, item 617, as amended), as well as several other Acts [15]. The introduction of a health care proxy is intended to increase the influence of the patient on decisions concerning treatment made in the circumstances of his or her incapacity to 
give consent, and to facilitate physicians' work with such patients and their families. In addition, it will provide the patient with the opportunity to appoint a selected person - a health care proxy - to represent the patient's will, values and interests. However, the most important benefit for physicians will be the possibility to provide such patients with health services without the need to obtain the consent of the guardianship court. The introduction of a health care proxy may also have a positive impact on the work of nurses and midwives, psychologists, physiotherapists, social workers, volunteers and other persons involved in the care of the patient who cannot or does not want to make decisions concerning medical care [16].

\section{Requirement to disclose information to the patient}

Making decisions about current and future medical procedures by the patient requires the physician to provide information concerning the patient's health condition. The scope of such information, the conditions for its provision and the persons entitled to receive it are regulated in detail in the Polish legal provisions. It should be emphasised that these regulations require physicians to implement the process of advance care planning in terms of information at various stages of medical care.

Requirement to disclose information to the patient is one of the basic principles of the medical profession and is regulated in Art. 31 of the Act of 05 December 1996 on Professions of Doctor and Dentist (Journal Of Laws [Dz. U.] of 2018, item 617, as amended). In accordance with this provision, the physician should provide the patient with information on the state of health, diagnosis, suggested and possible diagnostic methods, treatment results, as well as suggested and possible therapeutic methods, foreseeable effects of their application or omission and prognosis. Therefore, information provided to each patient should also include the possible future course of the disease, related to the state of health and treatment, which can be predicted according to current medical knowledge. It should be stressed that information on possible methods of treatment cannot be limited to causative treatment aimed at curing or prolonging survival. It should also involve explaining to the patient methods of pain management and treatment of other troublesome ailments, in particular the possibility of providing palliative care services.

Requirement to disclose information arises from the moment when the physician could and should have, in the light of the indications of current medical knowledge, diagnosed the patient with symptoms requiring the implementation of methods of diagnosis or treatment. This is particularly the case when, upon the examination of the patient, it may be stated that the criteria for eligibility for a specific form of care have been met. Postponing the implementation of this obligation exposes the physician to legal liability, and the patient and persons from his or her environment to adverse effects resulting from the lack of knowledge about relevant facts concerning the state of health. The patient, to the extent that he or she has not been informed, is deprived of the opportunity to make a full assessment of his or her situation and may therefore fail to take decisions regarding diagnosis and treatment that could be beneficial to him or her. For instance, informing the patient about a condition that qualifies for palliative care enables him or her to make a decision regarding a visit to the Palliative Medicine Outpatient Clinic in the event of troublesome ailments. Lack of relevant information may result in ineffective search for other forms of assistance and unnecessary suffering. Indication of the different options for medical treatment is the basis for the patient to make a conscious choice regarding the selection of treatment methods or the discontinuation of therapy, which also applies to the advance care planning.

It is the responsibility of the physician to inform the patient about the possible consequences of the application or abandonment of diagnostic and therapeutic methods, which obliges to inform the patient about both the near and more distant future. This information should be based primarily on an individual assessment of the patient's state of health, made on the basis of current medical knowledge. Additional factors need to be taken into account, such as scientific data concerning patients with similar clinical conditions, or the level of physician's skills and communication experience. The patient's knowledge gained on the basis of the information obtained from the physician and the awareness of the expected results of medical treatment may be of decisive importance when the patient decides whether to choose one or the other diagnostic or therapeutic method.

\section{Scope of information provided to the patient}

The possibility for the patient to make an informed choice between the available medical procedures, as well as to resign from an examination or treatment, is included in the patient's rights as set out in Art. 16 of the Act of 6 November 2008 on Patient Rights and the Patient Rights Ombudsman (Journal of Laws [Dz. U.] of 2017, item 1318, as amended). For the patient's consent or refusal to give consent to be effective, 
the physician should provide the patient with all the information listed in Art. $9 \mathrm{sec}$. 2 of the Act on Patient Rights and the Patient Rights Ombudsman. The above mentioned information should contain accessible information about the state of health, diagnosis, suggested and possible diagnostic and therapeutic methods, foreseeable consequences of their implementation or omission, results of treatment and prognosis. It should be emphasised that only complete information, i.e. including all the above mentioned elements, allows the physician to obtain the patient's consent, which is legally effective [17]. Art. 16 of the Act on Patient Rights and the Patient Rights Ombudsman stipulates that the patient has the right to consent or refuse to consent to the provision of certain health services, after being informed within the limits laid down in Art. 9 of the Act on Patient Rights and the Patient Rights Ombudsman.

The patient's right to be informed in the process of advance care planning, determines the disclosure requirement also on the part of healthcare professionals other than the physician. The precise scope of competences of the individual members of the interdisciplinary team, as a rule, resulting from legal regulations, does not allow for the delegation of the disclosure requirement to other persons, e.g. the physician may not order the psychologist to provide the patient with bad information about the prognosis. The fulfillment by persons involved in patient care of the above described information obligation enables patients to consider the significance and consequences of a possible course of a serious disease, define objectives and preferences for future medical treatment and care. This way, the Polish law provides conditions for advance care planning in accordance with the EAPC definition.

The provision of information is not the only obligation related to advance care planning provided for by law. Healthcare professionals are also obliged to listen to the patient's opinion as regards the extent to which they provided the patient with information concerning his or her state of health (Art. 9 sec. 5 of the Act on Patient Rights and the Patient Rights Ombudsman, in conjunction with Art. 2 thereof). Hearing the patient may help to identify his or her values, objectives and preferences, which should be taken into account during the provision of health services.

\section{Information on the possibility of discontinuation or withdrawal from treatment}

The process of advance care planning is also influenced by information on the consequences of discontinuation of diagnostic or therapeutic methods. Not only does it convince the patient to use the medical procedure proposed by the physician, but it is also intended to allow the patient to assess whether it is better for him or her in his or her individual situation to commence, continue, discontinue or withdraw from treatment. Complete information in this regard may protect the patient from overzealous therapy and unnecessary suffering caused by burdensome additional tests, the results of which will not affect further therapeutic procedures. The patient's objection to the proposed methods of treatment according to current medical knowledge does not exclude the possibility of informing the patient about other medical activities, the use of which in his or her situation is acceptable and in accordance with medical standards. In addition, in the above mentioned circumstances, the physician is obliged to inform the patient about the consequences of withdrawing from the proposed treatment.

If the use of available causative treatment does not have a beneficial effect on the patient, the physician should inform the patient about the possibility of withdrawing from treatment, as well as about the consequences of continuing the treatment. Moreover, in the light of Art. $38 \mathrm{sec}$. 2 of the Act on on Professions of Doctor and Dentist, in the case of withdrawal from treatment, the physician is obliged to inform the patient, his or her statutory representative or a de facto carer of this fact in advance, which constitutes the part of the advance care planning. If, in the situation described above, there are methods or procedures available which are consistent with the principles of current medical knowledge and which the patient could benefit from (e.g. palliative care), the physician should either apply them or indicate the possibilities of providing such services to another physician or therapist. On the other hand, Art. 37 of the Act on Patient Rights and the Patient Rights Ombudsman obliges the physician to consult a competent specialist or to convene a Medical Council in the event of diagnostic or therapeutic doubts, which may also apply to cases of withdrawal from treatment.

\section{Discussion of patient's objectives and preferences regarding medical care with his or her relatives}

Another activity that is part of the advance care planning is to discuss the patient's objectives and preferences regarding treatment with his or her family and with those involved in care. The provision of information by the physician to the patient's relatives and members of the therapeutic team is subject to strictly specified conditions resulting from the legal regulations. They define both the persons entitled to receive information and the circumstances under which it may be provided. The basic principle is to 
inform the persons authorised by the patient or his statutory representative (Art. $9 \mathrm{sec} .3$ of the Act on Patient Rights and the Patient Rights Ombudsman), or providing information to other persons on the basis of the consent granted by the patient (Art. $30 \mathrm{sec}$. 2 of the Act on Professions of Doctor and Dentist).

It should be taken into account that the persons indicated in the authorisation included in the medical records that are drawn up in connection with the admission of the patient to a medical facility may enjoy access to information concerning health to the same extent as those whom the patient has otherwise consented to be informed. Authorisation in medical records constitutes a written form of the patient's consent to access to information which excludes the obligation of physician-patient privilege. Patient's consent for information to be provided to others may be given and changed at any time, either verbally or in writing, and the patient may specify the scope of information to be disclosed and the persons authorised. It is worth noting that the authorisation to information granted by the patient to his or her relatives should also be considered as a pro futuro statement, effective in the more distant future, even after the patient has lost his or her ability to give consent.

When the patient is under the age of 16 , he or she is unconscious or incapable of understanding the meaning of information, Art. $31 \mathrm{sec}$. 6 of the Act on Professions of Doctor and Dentist imposes a requirement on the physician to disclose information to a relative. The closed catalogue of relatives includes the patient's spouse, relatives up to the second degree of consanguity or direct relatives up to the second degree of affinity, the patient's statutory representative, the person in cohabitation with the patient and the person indicated by him or her (Art. 3 sec. 1 item 2 of the Act on Patient Rights and the Patient Rights Ombudsman) [18]. The aforementioned provision allows for obtaining information by strictly defined relatives of the patient, both when the patient has authorised the person to receive information and when the person has not been indicated by the patient. Informing relatives is independent of the patient's will, in the light of Art. $31 \mathrm{sec} .6$ of the Act on Professions of Doctor and Dentist, which may raise doubts in situations where the patient has objected to the provision of information. There is no clear legal confirmation of the effectiveness of such an objection, which in practice may lead to a procedure contrary to the will and preferences of the patient.

Polish law does not prescribe any requirement for the physician to disclose information to authorised relatives of the patient, except in the case of informing his or her statutory representative or a person authorised by him or her in circumstances where the physician has limited the scope of information within a therapeutic privilege (Art. 31 sec. 1 and Art. 4 sentence 2 ), and if the patient is under 16 years of age, is unconscious or incapable of understanding the meaning of information and the request for information is made by a relative within the meaning of Art. 3 sec. 1 item 2 of the Act on Patient Rights and the Patient Rights Ombudsman. In other cases, the physician is only entitled to provide information on the basis of the patient's consent or authorisation. For instance, if an adult patient is able to understand the meaning of information, the doctor may provide information to a person he or she has authorised, but is not under any obligation to do so. The physician shall be obliged to disclose information to the authorised person when the patient loses consciousness. However, it is important from the perspective of advance care planning that the physician uses the possibility provided for by law to inform the relatives of the patient, even if the physician is not under any disclosure requirement (Art. $31 \mathrm{sec}$. 2 of the Act on Professions of Doctor and Dentist).

\section{Problems related to the application of the therapeutic privilege}

Abusing of therapeutic privilege by physicians may be a factor that adversely affects appropriate advance care planning, as it helps to limit the scope of information on health and prognosis provided to the patient when prognosis is bad, and in the physician's opinion it is in the patient's best interest. It should be emphasised that a therapeutic privilege is only acceptable under strict conditions specified by law, and that the scope of information that the physician may not provide is very narrow and precisely defined (Art. $31 \mathrm{sec} .4$ of the Act on on Professions of Doctor and Dentist). Within a therapeutic privilege, the physician should provide the patient with full information about the diagnosis, the proposed and applicable diagnostic and therapeutic methods, the foreseeable effects of their use or discontinuation, and the results of treatment, as this information must not be omitted. They have been specified in the provisions of law and listed in addition to information on the state of health other than the above mentioned and information on prognosis, which may be limited under conditions of therapeutic privilege, e.g. the physician is not allowed to omit information on cancer, because it is information on diagnosis; similarly, it is a violation of the principles of the medical profession to omit information on the possibility of providing palliative care, since it is information on possible 
therapeutic methods. In the case of the patient's request for information, the physician is obliged to inform the patient in a comprehensive manner, thus also about the patient's health and prognosis [19]. Patient's initiative to obtain information prevents the application of a therapeutic privilege.

\section{Provision of information in the therapeutic team}

Legal acts regulating the particular medical professions and provisions of the Act on Patient Rights and the Patient Rights Ombudsman (Art. 14 sec. 2 item 4) specify the scope of information to be communicated between the members of the therapeutic team involved in the patient's care, which also facilitates the transfer of information relevant from the perspective of advance care planning. In particular, Art. $14 \mathrm{sec}$. 2 item 4 of the Act on Patient Rights and the Patient Rights Ombudsman exempts healthcare professionals from the obligation of physician-patient privilege in circumstances when there is a need to provide information about the patient related to the provision of health services to other healthcare professionals participating in the provision of those services. An example of a specific solution for the provision of information in a therapeutic team is Art. 13 of the Act of 15 July 2011 on the occupation of nurses and midwives (Journal of Laws [Dz.U.] of 2018 item 123 as amended). In the light of this provision, a nurse has the right to obtain full information from the physician about the patient's state of health, diagnosis, proposed diagnostic, therapeutic, rehabilitation, preventive and foreseeable effects of the undertaken actions, to the extent necessary for the health services provided by him or her.

\section{Medical records of advance care planning}

Advance care planning requires the recording and regular verification of all patient preferences, which may involve making annotations in medical records, including acceptance of patient declarations of intent regarding medical procedures. In Polish legal regulations (the Act on Patient Rights and the Patient Rights Ombudsman and the provisions of the Regulation of the Minister of Health of 9 November 2015 on types, scope and templates of medical records and the manner in which they are to be processed (Journal of Laws [Dz. U.], item 2069), the obligation to include in medical records strictly defined statements concerning consent to tests, provision of other health services, authorisation to inform other persons and access to medical records was defined. However, they do not specify the conditions and forms of preparing pro futuro statements, which may cause doubts of the physician who receives such a statement from the patient. Nevertheless, the lack of specific regulation does not render such statements ineffective, and the inclusion in medical records of the patient's statement to be considered in the future, or the inclusion of a note stating that such a statement has been made, is not only lawful but also seems justified in view of the obligation to respect the patient's right to consent or refuse such consent.

\section{Physician's liability}

Polish law requires the physician to perform certain activities that constitute the process of advance care planning, in particular the disclosure of information to the patient that enables him or her to make informed decisions about current and more distant medical procedures. In this regard, the physician acts in violation of the law when he or she does not provide the patient with information, omits necessary information or limits its scope in an unlawful manner, for which he or she may incur civil, criminal, professional or employee liability. The physician's liability may then arise not only from a breach of the disclosure requirement, but also from acting without consent, which becomes ineffective because it has not been sufficiently explained [20].

Violation of the principles of the medical profession is one of the prerequisites for the liability of the physician. In this regard, failure to provide the patient with information or an unauthorised limitation of its scope, as well as an unjustified delay in its provision, may lead to the physician being convicted by a Medical Court in accordance with the procedure provided for in Art. 53 et seq. of the Act of 2 December 2009 on medical chambers (Journal Of Laws [Dz. U.] of 2018, item 168). Abuse of the therapeutic privilege and unjustified refusal to provide information or limitation of the scope of the information disclosed to the patient's statutory representative or a relative shall also be subject to the same liability. Failure to comply with the requirement to disclose information to the patient, to the extent and under the terms set out in Art. 9 et seq. of the Act on Patient Rights and the Patient Rights Ombudsman is subject to civil liability for infringement of patients' rights, which include the right to information and, in specific circumstances, the right to consent. The mere fact of culpable failure to disclose all the necessary information referred to above enables the injured party, upon request before a court of law, to be granted an appropriate sum by 
way of pecuniary compensation from the physician or medical facility, for the damage suffered, in accordance with Art. $4 \mathrm{sec} .1$ of the Act on Patient Rights and the Patient Rights Ombudsman.

If, as a result of an insufficient or late disclosure of information, the physician has caused harm to the patient, e.g. has not informed the patient about the possibility of receiving treatment for pain and other symptoms to which he or she could have been qualified, which has resulted in the patient's suffering, the patient may be entitled to seek pecuniary compensation. However, after the patient's death, the patient's spouse, relatives, direct relatives by affinity up to the second degree or a statutory representative may demand that an appropriate sum of money be awarded for a social purpose indicated by them, if a culpable violation of the right to die in peace and with dignity has occurred (Art. 4 sec. 2 of the Act on Patient Rights and the Patient Rights Ombudsman).

\section{Summary}

Advance care planning is a term that has not been widely recognised and applied in medical practice in Poland so far, however, persons involved in patient care implement to varying degrees the basic assumptions of the ACP defined in the definition of the international team of EAPC experts in 2017. Polish law also regulates only selected aspects of advance care planning, leaving aside solutions concerning advance directives and a health care proxy, which may cause doubts as to their applicability. In this context, the full implementation of the process of advance care planning requires the introduction of changes in the law consisting in the definition of detailed rules for the use of pro futuro statements and the conditions for appointing a health care proxy. The lack of a comprehensive regulation does not exclude, however, the possibility to plan care in advance, and the binding legal acts relating to disclosing information to the patient and authorised persons, communication in the therapeutic team, consent and objection to the provision of health services, provide in this respect for a number of requirements for healthcare professionals. Violation of these regulations may constitute the basis for the legal liability of medical facilities and persons employed by them, which justifies the introduction in medical practice and observance of procedures for advance care planning.

\section{References}

1. Rietjens J, Sudore $\mathrm{R}$, Connolly $\mathrm{M}$, et al. Definition and recommendations for advance care planning: an international consensus supported by the European Association for Palliative Care. The Lancet Oncology. 2017; 18(9): e543-e551, doi: 10.1016/s1470-2045(17)30582-x.

2. Kochan, K., Grądalski, T. Legal and ethical problems within palliative care for an incompetent patient. Palliative Medicine. 2015; 7(4): 223-227.

3. Grądalski, T., Kochan, K. Incompetent terminal patients' key carers expectations. Palliative Medicine. 2017; 9(1): 21-29.

4. Wesołek, E. Availability of palliative and hospice care for patients staying in nursing homes and long-term care facilities - rationale, possibilities and barriers. Palliative Medicine in Practice. 2016; 10(3): 112-118.

5. Krakowiak P., Paczkowska, A. Włączanie skazanych do wolontariatu opieki paliatywno-hospicyjnej na świecie i w Polsce. Dobre praktykłpracy systemu penitencjarnego ze środowiskiem opieki paliatywno-hospicyjnej w Polsce. Probacja. 2014; 2: 47-64.

6. Grądalski, T., Smyczyńska, M. Deactivation of implantable cardioverter-defibrillator at end of life. Palliative Medicine. 2015; 7(3): 201-204.

7. Sabatino CP. The evolution of health care advance planning law and policy. Milbank Q. 2010; 88(2): 211-239, doi: 10.1111/j.1468-0009.2010.00596.x, indexed in Pubmed: 20579283.

8. Pawłowski L. Problemy prawne w opiece paliatywnej. In: de Walden-Gałuszko K, Ciałkowska-Rysz A. ed. Medycyna Paliatywna. Wydawnictwo Lekarskie PZWL, Warszawa 2015: 445-456.

9. Bujny J. Advance Medical Directives of Jehovah's Witnesses: legal aspects. Anestezjol Ratow. 2008; 2: 195-200.

10. Janiszewska B. Praktyczne problemy oświadczeń pro futuro (uwagi po rozstrzygnięciu sprawy). Prawo i Medycyna. 2009; 4: 46-60.

11. Liszewska A. Criminal Responsibility for Medical Treatment Provided Without a Patient's Consent (Selected Aspects). Acta Universitatis Lodziensis. Folia luridica. 2015; 74: 71-82.

12. Bołoz W, Krajnik M, Adamczyk A. The definition of overzealous therapy. The consensus of the Polish Working Group on End-of-Life Ethics. Adv Palliat Med. 2008; 7(3): 91-92.

13. Smyk K. Legal character of the patient's consent in civil law. Folia luridica Universitatis Wratislaviensis. 2017; 6(1): 121-138.

14. Szeroczyńska M, Czarkowski M, Krajnik M, et al. Institution of the health care agent in Polish legislation: position of the Polish Working Group on End-of-Life Ethics. Polish Archives of Internal Medicine. 2016; 126(5): 313-320, doi: 10.20452/pamw.3405.

15. Szeroczyńska M, Czarkowski M, Krajnik M, et al. Instytucja pełnomocnika medycznego w Polsce - stanowisko Polskiej Grupy Roboczej ds. Problemów Etycznych Końca Życia. Med Prakt. 2016; 330(5): 102-111.

16. Zurzycka P, Czyżowicz K, Repka I. The institution of the health care agent vs. nursing practice - an outline of issues. Probl Piel. 2018; 26(1): 64-68.

17. Baron K. Zgoda pacjenta. Prokuratura i Prawo. 2010; 9: 42-57.

18. Pawłowski L. Close person in the light of giving information concerning patient's state of health (part 2). Forum Medycyny Rodzinnej. 2014; 8(4): 195-200.

19. Karkowska, D. Ustawa o prawach pacjenta i Rzeczniku Praw Pacjenta: Komentarz. [Act on Patient Rights and the Patient Rights Ombudsman: Commentary]. Wolters Kluwer, Warszawa 2012: 169.

20. Niemczyk S, Łazarska A. Materialnoprawne elementy aktu zgody pacjenta $w$ ujęciu prawnym i medycznym. Prawo i Medycyna. 2005; 19(7): 48-65. 


\section{Wybrane aspekty planowania opieki z wyprzedzeniem w kontekście polskiego prawa — obowiązki lekarza}

Artykuł jest tłumaczeniem pracy: Pawłowski L., Modlińska A., Lichodziejewska-Niemierko M., Selected aspects of advance care planning according to Polish legal regulations - physician's requirements. Palliat. Med. Pract. 2019 tom 13, nr 4: $197-203$. Należy cytować wersję pierwotną. Piśmiennictwo znajduje się na stronie 203.

\section{Streszczenie}

W 2017 roku grupa 109 ekspertów z różnych krajów opracowała w formie konsensusu międzynarodową definicję planowania opieki z wyprzedzeniem (ACP, advance care planning), której istotą jest umożliwienie osobom określenie ich celów i preferencji dotyczących przyszłego leczenia i opieki medycznej, omówienie ich z rodziną i osobami udzielającymi świadczeń zdrowotnych, ich dokumentowanie i sprawdzanie. Planowanie opieki z wyprzedzeniem odgrywa istotną rolę w opiece nad pacjentami z chorobami przewlekłymi, zwłaszcza w opiece paliatywnej, ich rodzinami, dotyczy również pracowników jednostek, w których taka opieka jest zapewniana.

W artykule przedstawiono uwarunkowania prawne i wybrane aspekty planowania opieki z wyprzedzeniem w Polsce. Do podstawowych elementów planowania opieki z wyprzedzeniem należy informowanie pacjenta i branie pod uwagę jego decyzji dotyczących leczenia i opieki medycznej. Polskie prawo nakłada na osoby wykonujące zawody medyczne obowiązki z tym związane i określa szczegółowe zasady przekazywania członkom rodziny chorego informacji o stanie zdrowia, rozpoznaniu i prognozie. Jednak w polskim prawodawstwie oświadczenia na przyszłość (pro futuro) i instytucja pełnomocnika medycznego nie zostały dotychczas wprowadzone, dlatego wydaje się, że włączenie planowania opieki z wyprzedzeniem do polskiego systemu opieki zdrowotnej wymaga nowych regulacji prawnych.

Słowa kluczowe: planowanie opieki z wyprzedzeniem, prawo, świadoma zgoda, Polska

Palliat Med Pract 2019; 13, 4: 204-210

\section{Wstęp}

We wrześniu 2017 roku w czasopiśmie The Lancet Oncology opublikowano wyniki prac międzynarodowego zespołu ekspertów Europejskiego Towarzystwa Opieki Paliatywnej (EAPC, European Association for Palliative Care) [1]. Opierając się na opinii 109 specjalistów z Europy, Ameryki Północnej i Australii, z zastosowaniem metody Delphi, wypracowano konsensus w zakresie planowania opieki z wyprzedzeniem (ACP, advance care planning). Zgodnie ze stanowiskiem ekspertów EAPC ustalono definicję, według której planowanie opieki z wyprzedzeniem umożliwia osobom posiadającym zdolność do świadomego podejmowania decyzji:

\section{Adres do korespondencji:}

Leszek Pawłowski

Department of Palliative Medicine, Medical University of Gdańsk

e-mail: Ipawlowski@gumed.edu.pl 
1. zidentyfikowanie ich wartości;

2. rozważenie znaczenia i konsekwencji możliwego przebiegu poważnej choroby;

3. zdefiniowanie celów i preferencji w zakresie przyszłego postępowania medycznego i opieki.

4. Omówienie powyższych zagadnień z rodziną i z osobami sprawującymi opiekę medyczną.

Planowanie opieki z wyprzedzeniem odnosi się do sfery fizycznej, psychicznej, socjalnej i duchowej osoby, zachęca do ustanowienia osobistego przedstawiciela, rejestrowania i regularnej weryfikacji wszelkich oświadczeń woli tak, aby preferencje mogły być brane pod uwagę, jeżeli w przyszłości osoba będzie niezdolna do podejmowania decyzji [1].

Metody postępowania ACP nie są powszechnie stosowane w polskiej praktyce medycznej, a liczba publikacji naukowych dotyczących tego zagadnienia w Polsce jest niewielka. Dotychczas w języku polskim brak jednolitego nazewnictwa tego rodzaju sposobu postępowania wobec pacjenta. W dostępnym polskim piśmiennictwie ACP jest tłumaczone jako planowanie na przyszłość opieki u kresu życia, planowanie wspólnie z chorym opieki medycznej na końcu życia czy planowanie opieki z wyprzedzeniem. Można spotkać określenie ACP rozumiane jako pisemnie wyrażona przez chorego wola dotycząca postępowania medycznego w zaawansowanym okresie choroby albo wyłącznie planowanie opieki lub planowanie leczenia [2-6]. W świetle definicji EAPC, ACP wykracza poza zakres planowania opieki u kresu życia lub planowania leczenia, a ponadto nie ogranicza się wyłącznie do wyrażenia woli przez chorego, gdyż obejmuje także informowanie pacjenta i przekazywanie informacji członkom rodziny. W niniejszym artykule pojęcie advanced care planning przetłumaczono, jako „planowanie opieki z wyprzedzeniem”, które w opinii autorów artykułu, najbardziej odpowiada definicji opracowanej przez zespół ekspertów EAPC [1]. W znaczeniu prawnym planowanie opieki $z$ wyprzedzeniem jest $z$ reguły rozpatrywane w odniesieniu do poniższych zagadnień.

1. Oświadczenia na przyszłość (pro futuro) składanego przez pacjentów na wypadek utraty zdolności do decydowania o przyszłej opiece i postępowaniu medycznym.

2. Ustanowienie przez pacjenta pełnomocnika medycznego na wypadek zaistnienia okoliczności wymienionych w poprzednim punkcie.

3. Regulacje prawne dotyczące komunikowania się z pacjentem i jego rodziną w zakresie ustalenia woli i preferencji dotyczących przyszłej opieki, a także przepisy prawne dotyczące postępowania wobec chorego, na podstawie wcześniej wyrażonej woli [7].

\section{Oświadczenia na przyszłość (pro futuro)}

W Polsce dotychczas nie ustanowiono przepisów prawnych określających kryteria stosowania w praktyce medycznej oświadczeń „na przyszłość” - pro futuro. Nie oznacza to, że tego rodzaju oświadczenia, złożone uprzednio przez pacjenta, nie wywołują skutków prawnych [8-10]. Zgodnie z przepisami prawa, upływ czasu nie stanowi okoliczności, która powoduje nieważność lub utratę skuteczności oświadczenia pacjenta, co do zgody lub sprzeciwu na udzielanie świadczeń zdrowotnych. Za wiążącym charakterem tego rodzaju oświadczeń opowiedział się między innymi Sąd Najwyższy (SN). W świetle uzasadnienia postanowienia z dnia 27.10.2005 r. (III CK 155/05), lekarz powinien brać pod uwagę uprzednie oświadczenia pacjenta dotyczące przyszłego postępowania medycznego, jeżeli zostały złożone w sposób wyraźny, jednoznaczny i nie budzą innych wątpliwości. W praktyce jednak ocena skuteczności tego rodzaju oświadczeń może powodować trudności związane z brakiem szczegółowych przepisów prawnych określających zasady ich stosowania [11]. Obok ustanowienia przepisów dotyczących oświadczeń pro futuro, celowe wydaje się wprowadzenie do polskiego prawa rozwiązań wyznaczających granice terapii medycznych, jak na przykład definicja uporczywej terapii, ustalona przez Polską Grupę Roboczą ds. Problemów Etycznych Końca Życia. Definicja określa warunki rezygnacji z postępowania i leczenia, które może przedłużyć okres umierania, narazić na niepotrzebne cierpienie i naruszenie godności pacjenta [12].

\section{Pełnomocnik medyczny}

W Polsce dotychczas nie wprowadzono możliwości wskazania przez pacjenta osoby, która będzie mogła w jego imieniu podejmować decyzje dotyczące postępowania medycznego. Na podstawie przepisów Kodeksu Cywilnego może być co prawda ustanowiony pełnomocnik, który wykonuje czynności prawne na rzecz reprezentowanego, nie jest on jednak uprawniony do składania oświadczeń wyrażenia zgody lub sprzeciwu na udzielanie pacjentowi świadczeń zdrowotnych. Tego rodzaju oświadczenia, według przeważających w doktrynie opinii, nie są oświadczeniami woli w rozumieniu prawa cywilnego. Pełnomocnik działający na podstawie przepisów Kodeksu Cywilnego nie został bowiem zaliczony do zamkniętego katalogu uprawnionych do wyrażenia zgody na udzielanie świadczeń zdrowotnych. Należy przypomnieć, że obok samego pacjenta, do zamkniętej grupy uprawnionych należy jego przedstawiciel ustawowy, sąd opiekuńczy, a w ograniczonym zakresie także opiekun faktyczny [13]. 
Propozycję rozwiązań prawnych w tym zakresie przygotowała Polska Grupa Robocza ds. Problemów Etycznych Końca Życia, która postuluje wprowadzenie instytucji pełnomocnika medycznego, ustanawianego przez pacjenta, wraz z zakresem jego kompetencji [14]. Proponowane rozwiązanie nie jest rodzajem pełnomocnictwa przewidzianego w Kodeksie Cywilnym, lecz stanowi zupełnie nową formę reprezentacji pacjenta. Jej implementacja do polskiego prawa wymagałaby zmiany w przepisach ustawy z dnia 6 listopada 2008 roku o prawach pacjenta i Rzeczniku Praw Pacjenta (Dz. U. z 2017 r. poz. 1318 ze zm.) i ustawy z dnia 5 grudnia 1996 roku o zawodach lekarza i lekarza dentysty (Dz. U. z 2018 r. poz. 617 ze zm.), a także kilku innych ustaw [15]. Wprowadzenie pełnomocnika medycznego ma służyć zwiększeniu wpływu chorego na decyzje dotyczące leczenia, podejmowane w okolicznościach utraty przez niego zdolności do wyrażenia zgody, a także ułatwić lekarzom pracę z takimi pacjentami i ich rodzinami. Ponadto, umożliwi pacjentowi ustanowienie wybranej osoby — pełnomocnika medycznego, która będzie reprezentowała wolę, wartości i interesy chorego. Natomiast, najważniejszą korzyścią dla lekarzy będzie możliwość udzielania takim pacjentom świadczeń zdrowotnych bez potrzeby uzyskania zezwolenia sądu opiekuńczego. Wprowadzenie pełnomocnika medycznego może również pozytywnie oddziaływać na pracę pielęgniarek i położnych, psychologów, fizjoterapeutów, pracowników socjalnych, wolontariuszy i innych osób zaangażowanych w opiekę nad pacjentem, który nie może lub nie chce podejmować decyzji dotyczących opieki medycznej [16].

\section{Obowiązek informowania pacjenta}

Podejmowanie przez chorego decyzji o aktualnym i przyszłym postępowaniu medycznym wymaga od lekarza uprzedniego przekazania informacji dotyczących stanu zdrowia pacjenta. Zakres tych informacji, warunki ich przekazywania i osoby uprawnione do ich otrzymania, zostały szczegółowo uregulowane w przepisach polskiego prawa. Należy podkreślić, że przepisy te wymagają od lekarza realizacji procesu planowania opieki z wyprzedzeniem w aspekcie informacyjnym na różnych etapach opieki medycznej.

Obowiązek informowania pacjenta zalicza się do podstawowych zasad wykonywania zawodu lekarza i jest uregulowany w art. 31 ustawy z dnia 5 grudnia 1996 roku o zawodach lekarza i lekarza dentysty (Dz. U. z 2018 r. poz. 617 ze zm., zwanej dalej „u.z.I.”). Zgodnie z tym przepisem, lekarz powinien przekazywać pacjentowi informacje o stanie zdrowia, rozpoznaniu, proponowanych i możliwych metodach diagnostycznych, wynikach leczenia, a także o proponowanych i możliwych metodach leczniczych, dających się przewidzieć następstwach ich zastosowania albo zaniechania i o rokowaniu. Informacja udzielana każdemu pacjentowi powinna więc dotyczyć również możliwego przebiegu choroby w przyszłości, związanego ze stanem zdrowia i leczeniem, które można przewidzieć według aktualnej wiedzy medycznej. Należy podkreślić, że informacja o możliwych metodach leczenia nie może ograniczać się jedynie do postępowania przyczynowego, którego celem jest wyleczenie albo wydłużenie czasu przeżycia. Powinna ona obejmować również wyjaśnienie pacjentowi metod postępowania polegających na leczeniu bólu i innych uciążliwych objawów, zwłaszcza możliwości zapewnienia świadczeń w zakresie opieki paliatywnej.

Obowiązek przekazania informacji powstaje z chwilą, gdy lekarz mógł i powinien był, w świetle wskazań aktualnej wiedzy medycznej, stwierdzić u pacjenta wystąpienie objawów wymagających wdrożenia metod diagnostyki lub leczenia. Ma to miejsce zwłaszcza wówczas, kiedy ocena stanu chorego wskazuje na spełnienie kryteriów kwalifikujących pacjenta do objęcia określoną formą opieki. Odkładanie w czasie realizacji tego obowiązku naraża lekarza na odpowiedzialność prawną, a pacjenta i osoby z jego otoczenia, na niekorzystne skutki wynikające z braku wiedzy na temat istotnych faktów dotyczących stanu zdrowia. Chory w zakresie, w jakim nie otrzymał informacji, zostaje pozbawiony możliwości dokonania pełnej oceny swojej sytuacji, dlatego może nie podjąć decyzji dotyczących diagnostyki i leczenia, które mogłyby być dla niego korzystne. Na przykład poinformowanie chorego o stanie zdrowia kwalifikującym do objęcia opieką paliatywną umożliwia pacjentowi decyzję o wizycie w poradni medycyny paliatywnej w sytuacji wystąpienia uciążliwych objawów. Brak właściwej informacji może powodować bezskuteczne poszukiwanie innych form pomocy i niepotrzebne cierpienie. Wskazanie różnych możliwości postępowania medycznego jest podstawą dokonania przez pacjenta świadomego wyboru metod leczenia lub rezygnacji z terapii, co dotyczy także podjęcia działań w zakresie planowania opieki z wyprzedzeniem.

Do zakresu obowiązków lekarza należy przekazywanie pacjentowi informacji o możliwych następstwach zastosowania lub zaniechania metod diagnostycznych i leczniczych, co obliguje do informowania chorego zarówno o bliższej, jak i bardziej odległej przyszłości. Informacje te powinny opierać się głównie na indywidualnej ocenie stanu zdrowia chorego, dokonanej na podstawie aktualnej wiedzy medycznej. Uwzględnić trzeba dodatkowe czynniki, takie jak dane naukowe dotyczące chorych o podobnym stanie 
klinicznym czy poziom umiejętności lekarza i doświadczenie w zakresie komunikowania się. Wiedza pacjenta zdobyta na podstawie informacji uzyskanej od lekarza i świadomość przewidywanych skutków postępowania medycznego może mieć decydujące znaczenie przy wyborze przez chorego jednych i rezygnacji z innych metod diagnostycznych lub terapeutycznych.

\section{Zakres informacji przekazywanych pacjentowi}

Możliwość dokonania przez pacjenta świadomego wyboru pomiędzy dostępnymi metodami postępowania medycznego, a także rezygnacji z badań lub leczenia, zalicza się do praw pacjenta, określonych $w$ art. 16 ustawy z dnia 6 listopada 2008 roku o prawach pacjenta i Rzeczniku Praw Pacjenta (Dz. U. z 2017 r. poz. 1318 ze zm., zwanej dalej „u.p.p."). Aby zgoda pacjenta lub odmowa jej wyrażenia były skuteczne, lekarz powinien przekazać choremu wszystkie informacje wymienione $w$ art. 9 ust. 2 u.p.p. Nie może wśród nich zabraknąć przystępnej informacji o stanie zdrowia, rozpoznaniu, proponowanych i możliwych metodach diagnostycznych i leczniczych, dających się przewidzieć następstwach ich zastosowania albo zaniechania, wynikach leczenia i rokowaniu. Należy podkreślić, że jedynie pełna informacja, a więc obejmująca wszystkie wymienione elementy, pozwala na uzyskanie przez lekarza zgody pacjenta, która jest skuteczna pod względem prawnym [17]. Artykuł 16 u.p.p. stanowi bowiem, że pacjent ma prawo do wyrażenia zgody na udzielenie określonych świadczeń zdrowotnych lub odmowy takiej zgody, po uzyskaniu informacji w zakresie określonym w art. 9 u.p.p.

Prawo pacjenta do uzyskania informacji w procesie planowania opieki z wyprzedzeniem kształtuje obowiązek informacyjny również po stronie innych, niż lekarz osób wykonujących zawód medyczny. Ścisły zakres kompetencji poszczególnych członków zespołu interdyscyplinarnego, wynikający z przepisów prawa, $z$ reguły nie pozwala na delegowanie obowiązku przekazywania informacji na inne osoby, na przykład lekarz nie może zlecić psychologowi przekazania pacjentowi niepomyślnej informacji o rokowaniu. Realizacja przez osoby zaangażowane w opiekę nad pacjentem wyżej opisanego obowiązku informacyjnego umożliwia pacjentom rozważenie znaczenia i konsekwencji możliwego przebiegu poważnej choroby, zdefiniowanie celów i preferencji w zakresie przyszłego postępowania medycznego i opieki. W ten sposób polskie prawo stwarza warunki do realizacji planowania opieki z wyprzedzeniem, zgodnie z definicją EAPC.

Przekazywanie informacji nie jest jedynym obowiązkiem związanym z planowaniem opieki z wyprzedze- niem przewidzianym w przepisach prawa. Osoby wykonujące zawód medyczny są również zobowiązane do wysłuchania zdania pacjenta w zakresie, w jakim przekazywały choremu informacje dotyczące stanu zdrowia (art. 9 ust. 5 u.p.p., w związku z art. 2 tej ustawy). Wysłuchanie pacjenta może pozwolić na zidentyfikowanie jego wartości, celów i preferencji, które powinny być brane pod uwagę podczas udzielania świadczeń zdrowotnych.

\section{Informacja o możliwości zaniechania lub niepodejmowania leczenia}

Na przebieg planowania opieki z wyprzedzeniem wpływa również informacja o skutkach zaniechania metod diagnostycznych lub leczniczych. Nie służy ona jedynie do przekonania pacjenta, aby skorzystał z proponowanego przez lekarza postępowania medycznego, ale ma pozwolić choremu na ocenę, czy $w$ jego indywidualnej sytuacji lepszym rozwiązaniem będzie podjęcie, kontynuowanie czy też zaniechanie lub zaprzestanie leczenia. Pełna informacja w tym zakresie może uchronić pacjenta przed zastosowaniem uporczywej terapii i niepotrzebnym cierpieniem wywołanym wykonywaniem uciążliwych badań dodatkowych, których wyniki nie wpłyną na dalsze postępowanie terapeutyczne. Sprzeciw pacjenta wobec proponowanych metod postępowania według aktualnej wiedzy medycznej nie wyklucza możliwości poinformowania chorego o innych działaniach medycznych, których zastosowanie w jego sytuacji jest dopuszczalne i zgodnie ze standardami medycznymi. Ponadto, w wyżej opisanych okolicznościach, na lekarzu ciąży obowiązek poinformowania pacjenta o skutkach rezygnacji z proponowanych świadczeń.

W okolicznościach, kiedy zastosowanie dostępnych metod leczenia przyczynowego nie spowoduje korzystnego dla pacjenta skutku, lekarz powinien poinformować pacjenta o możliwości odstąpienia od leczenia, a także o konsekwencjach wynikających z jego kontynuowania. Ponadto, w świetle art. 38 ust. 2 u.z.l., w przypadku odstąpienia od leczenia, lekarz ma obowiązek dostatecznie wcześnie uprzedzić o tym fakcie pacjenta, jego przedstawiciela ustawowego bądź opiekuna faktycznego, co należy do działań z zakresu planowania opieki z wyprzedzeniem. Jeżeli w wyżej opisanej sytuacji są dostępne metody lub sposoby postępowania zgodne $z$ zasadami aktualnej wiedzy medycznej, z których pacjent mógłby skorzystać (np. opieka paliatywna), lekarz powinien albo je zastosować, albo wskazać możliwości zapewnienia tego rodzaju świadczeń u innego lekarza lub w podmiocie leczniczym. Z kolei, art. 37 u.z.l. zobowiązuje lekarza do zasięgnięcia opinii 
właściwego specjalisty lub zwołania konsylium lekarskiego w okolicznościach, kiedy wystąpią wątpliwości diagnostyczne lub terapeutyczne, co może dotyczyć także przypadków odstąpienia od leczenia.

\section{Omóvienie celów i preferencji pacjenta dotyczących opieki medycznej z osobami z jego otoczenia}

Kolejnym działaniem zaliczanym do planowania opieki z wyprzedzeniem jest omówienie celów i preferencji chorego dotyczących leczenia z jego rodziną i osobami zaangażowanymi w opiekę. Przekazywanie informacji przez lekarza osobom bliskim pacjenta i członkom zespołu terapeutycznego podlega ściśle określonym warunkom wynikającym z przepisów prawa. Regulują one zarówno osoby uprawnione do uzyskania informacji, jak i okoliczności, pozwalające na ich przekazanie. Podstawową zasadą jest informowanie osób upoważnionych przez pacjenta lub jego przedstawiciela ustawowego (art. 9 ust. 3 u.p.p.) albo udzielanie informacji innym osobom na podstawie zgody wyrażonej przez pacjenta (art. 30 ust. 2 u.z.l.).

Należy uwzględnić, że osoby wskazane $\mathrm{w}$ upoważnieniu zawartym w dokumentacji medycznej, które jest sporządzane w związku z przyjęciem pacjenta do placówki medycznej, mogą korzystać z dostępu do informacji dotyczących zdrowia w takim samym zakresie, jak osoby, na których informowanie pacjent wyraził zgodę $w$ inny sposób. Upoważnienie w dokumentacji medycznej stanowi pisemną formę zgody pacjenta na dostęp do informacji, która wyłącza obowiązek zachowania tajemnicy lekarskiej. Zgoda pacjenta na przekazanie informacji innym osobom może zostać wyrażona i zmieniona w każdym czasie, zarówno ustnie, jak i w formie pisemnej, a pacjent ma prawo określić zakres przekazywanych informacji i osoby uprawnione. Warto podkreślić, że upoważnienie do informacji udzielone przez pacjenta osobom $z$ jego otoczenia powinno być rozpatrywane również jako oświadczenie pro futuro, skuteczne w bardziej odległej przyszłości, także po utracie przez pacjenta zdolności do wyrażenia zgody.

W okolicznościach, kiedy pacjent nie ukończył 16 lat, jest nieprzytomny lub niezdolny do zrozumienia znaczenia informacji, art. 31 ust. 6 u.z.l. nakłada na lekarza obowiązek przekazania informacji osobie bliskiej. Do zamkniętego katalogu osób bliskich należy małżonek pacjenta, krewni do drugiego stopnia lub powinowaci do drugiego stopnia w linii prostej, przedstawiciel ustawowy pacjenta, osoba pozostająca z pacjentem we wspólnym pożyciu i osoba przez niego wskazana (art. 3 ust. 1 pkt 2 u.p.p.) [18]. Wyżej wymieniony przepis pozwala na uzyskanie informacji przez ściśle określone osoby z oto- czenia pacjenta, zarówno w sytuacji, kiedy upoważnił on osobę do informacji, jak i wówczas, gdy taka osoba nie została przez niego wskazana. Informowanie osób bliskich jest niezależne od woli pacjenta, w świetle art. 31 ust. 6 u.z.l., co może powodować wątpliwości w sytuacjach, kiedy pacjent sprzeciwił się przekazywaniu im informacji. Brakuje w przepisach prawa jednoznacznego potwierdzenia skuteczności takiego sprzeciwu, co może w praktyce prowadzić do postępowania sprzecznego z wolą i preferencjami pacjenta.

Polskie prawo nie przewiduje obowiązku przekazywania przez lekarza informacji uprawnionym osobom z otoczenia pacjenta, poza przypadkami informowania jego przedstawiciela ustawowego lub osoby przez niego upoważnionej w okolicznościach, kiedy lekarz ograniczył zakres informacji w warunkach przywileju terapeutycznego (art. 31 ust. 1 i ust. 4 zdanie 2), a także wówczas, gdy pacjent nie ukończył 16 lat, jest nieprzytomny lub niezdolny do zrozumienia znaczenia informacji, a prośba o przekazanie informacji pochodzi od osoby bliskiej w rozumieniu art. 3 ust. 1 pkt 2 u.p.p. W innych przypadkach lekarz jest jedynie uprawniony do przekazywania informacji na podstawie zgody lub upoważnienia pacjenta. Na przykład w sytuacji, kiedy dorosły pacjent jest zdolny do zrozumienia znaczenia informacji, lekarz może przekazać informacje upoważnionej przez niego osobie, lecz nie ma obowiązku jej poinformowania. Lekarz będzie miał obowiązek przekazania informacji osobie upoważnionej, po utracie przez pacjenta przytomności. Istotne z perspektywy planowania opieki z wyprzedzeniem jest jednak korzystanie przez lekarza z przewidzianej przez prawo możliwości informowania osób z otoczenia pacjenta, również wówczas, kiedy lekarz nie ma obowiązku przekazywania informacji (art. 31 ust. 2 u.z.l.).

\section{Problemy związane ze stosowaniem przywileju terapeutycznego}

Czynnikiem, który może negatywnie wpływać na prawidłowe planowanie opieki z wyprzedzeniem może być nadużywanie przez lekarzy przywileju terapeutycznego, który pozwala na ograniczenie zakresu informacji o stanie zdrowia i rokowaniu, przekazywanych pacjentowi, kiedy rokowanie jest niepomyślne, a w ocenie lekarza przemawia za tym dobro chorego. Należy podkreślić, że przywilej terapeutyczny jest dopuszczalny wyłącznie w ściśle określonych przez prawo warunkach, a zakres informacji, których lekarz może nie przekazać jest bardzo wąski i dokładnie określony (art. 31 ust. 4 u.z.I.). W warunkach przywileju terapeutycznego lekarz powinien przekazać choremu w pełnym zakresie informacje o rozpoznaniu, proponowanych i możliwych do zastosowania metodach diagnostycznych 
i leczniczych, dających się przewidzieć następstwach ich zastosowania lub zaniechania, a także wynikach leczenia, ponieważ informacje te nie mogą zostać pominięte. Zostały one w przepisach prawa wyodrębnione i wymienione, obok informacji o stanie zdrowia, innych niż wyżej wymienionych i informacji o rokowaniu, które mogą zostać ograniczone w warunkach przywileju terapeutycznego, na przykład lekarz nie może pominąć informacji o chorobie nowotworowej, ponieważ jest to informacja o rozpoznaniu; podobnie naruszeniem zasad wykonywania zawodu lekarza jest pominięcie informacji o możliwości zapewnienia opieki paliatywnej, ponieważ jest to informacja o możliwych metodach leczniczych. W przypadku prośby pacjenta o przekazanie informacji, na lekarzu ciąży obowiązek poinformowania chorego $\mathrm{w}$ pełnym zakresie, a więc również o stanie zdrowia i rokowaniu [19]. Inicjatywa pacjenta w zakresie uzyskania informacji uniemożliwia zastosowanie przywileju terapeutycznego.

\section{Przekazywanie informacji w zespole terapeutycznym}

Akty prawne regulujące wykonywanie poszczególnych zawodów medycznych i przepisy u.p.p. (art. 14 ust. 2 pkt 4) określają zakres informacji przekazywanych pomiędzy członkami zespołu terapeutycznego zaangażowanymi w opiekę nad pacjentem, co również pozwala na przepływ informacji istotnych z perspektywy planowania opieki z wyprzedzeniem. W szczególności art. 14 ust. 2 pkt 4 u.p.p. zwalnia osoby wykonujące zawód medyczny z obowiązku zachowania tajemnicy w okolicznościach, kiedy zachodzi potrzeba przekazania informacji o pacjencie związanych z udzielaniem świadczeń zdrowotnych innym osobom wykonującym zawód medyczny, uczestniczącym w udzielaniu tych świadczeń. Przykładem konkretnego rozwiązania dotyczącego przekazywania informacji w zespole terapeutycznym jest art. 13 ustawy $z$ dnia 15 lipca 2011 roku o zawodach pielęgniarki i położnej (Dz.U. z 2018 r. poz. 123 ze zm.). W świetle tego przepisu pielęgniarka ma prawo do uzyskania od lekarza pełnej informacji o stanie zdrowia pacjenta, rozpoznaniu, proponowanych metodach diagnostycznych, leczniczych, rehabilitacyjnych, zapobiegawczych i dających się przewidzieć następstwach podejmowanych działań, w zakresie niezbędnym do udzielanych przez siebie świadczeń zdrowotnych.

\section{Dokumentacja medyczna planowania opieki z wyprzedzeniem}

Planowanie opieki z wyprzedzeniem zakłada rejestrowanie i regularną weryfikację wszelkich prefer- encji pacjenta, co może nastąpić poprzez sporządzanie adnotacji w dokumentacji medycznej, w tym przyjmowanie od pacjenta oświadczeń woli dotyczących postępowania medycznego. W polskich przepisach prawnych (u.p.p. oraz przepisy rozporządzenia Ministra Zdrowia $z$ dnia 9 listopada 2015 r. w sprawie rodzajów, zakresu i wzorów dokumentacji medycznej oraz sposobu jej przetwarzania - Dz. U. poz. 2069) został uregulowany obowiązek umieszczenia w dokumentacji medycznej ściśle określonych oświadczeń dotyczących zgody na badania, udzielanie innych świadczeń zdrowotnych, upoważnienia do informowania innych osób i dostępu do dokumentacji medycznej. Nie regulują one natomiast warunków i formy sporządzania oświadczeń pro futuro, co może powodować wątpliwości lekarza, który przyjmuje takie oświadczenie od pacjenta. Niemniej jednak, brak szczegółowej regulacji nie powoduje nieskuteczności takich oświadczeń, a dołączanie do dokumentacji medycznej oświadczenia pacjenta, które będzie rozpatrywane w przyszłości lub zamieszczanie adnotacji o złożeniu takiego oświadczenia jest nie tylko dopuszczalne $w$ świetle prawa, ale również wydaje się zasadne, z uwagi na obowiązek poszanowania prawa pacjenta do wyrażenia zgody lub odmowy takiej zgody.

\section{Odpowiedzialność prawna lekarza}

Polskie prawo wymaga od lekarza stosowania wybranych działań, które składają się na proces planowania opieki z wyprzedzeniem, co dotyczy zwłaszcza przekazywania pacjentowi informacji, które umożliwiają podejmowanie przez niego świadomych decyzji o aktualnym i bardziej odległym postępowaniu medycznym. W związku z powyższym, lekarz postępuje $z$ naruszeniem prawa, kiedy nie przekazuje choremu informacji, pomija niezbędne informacje lub w sposób nieuprawniony ogranicza ich zakres, za co może ponieść odpowiedzialność cywilną, karną, zawodową lub pracowniczą. Odpowiedzialność lekarza może wówczas wynikać nie tylko z naruszenia obowiązku informacyjnego, ale również z działania bez zgody, która staje się nieskuteczna, ze względu na to, że nie została dostatecznie objaśniona [20].

Naruszenie przepisów związanych z wykonywaniem zawodu stanowi jedną z przesłanek odpowiedzialności zawodowej lekarza. W tym świetle, nieprzekazanie pacjentowi informacji lub nieuprawnione ograniczenie jej zakresu, a także nieuzasadnione opóźnienie jej przekazania może doprowadzić do skazania lekarza przez sąd lekarski w trybie przewidzianym w art. 53 i następnych ustawy z dnia 2 grudnia 2009 roku o izbach lekarskich (Dz. U. z 2018 r. poz. 
168). Tej samej odpowiedzialności podlega również nadużywanie przywileju terapeutycznego i nieuzasadniona odmowa przekazania informacji lub ograniczenie jej zakresu wobec przedstawiciela ustawowego pacjenta lub jego osoby bliskiej. Niedopełnienie obowiązku informowania pacjenta, w zakresie i na zasadach określonych w art. 9 i następnych u.p.p. podlega odpowiedzialności cywilnej za naruszenie praw pacjenta, do których należy prawo do informacji, a w szczególnych okolicznościach, także prawo do wyrażenia zgody. Sam fakt zawinionego nieprzekazania wszystkich niezbędnych informacji, które wymieniono powyżej, pozwala poszkodowanemu na żądanie przed sądem od lekarza lub placówki ochrony zdrowia przyznania odpowiedniej sumy tytułem zadośćuczynienia pieniężnego za doznaną krzywdę, zgodnie $z$ art. 4 ust. 1 u.p.p.

Jeżeli w wyniku niedostatecznego lub zbyt późnego przekazania informacji lekarz wyrządził pacjentowi szkodę na osobie, na przykład nie poinformował chorego o możliwości skorzystania z leczenia bólu i innych objawów, do którego mógł zostać zakwalifikowany, co spowodowało cierpienie pacjenta, choremu może przysługiwać roszczenie o zadośćuczynienie pieniężne. Natomiast, po śmierci pacjenta jego małżonek, krewni lub powinowaci do drugiego stopnia w linii prostej lub przedstawiciel ustawowy mogą żądać zasądzenia odpowiedniej sumy pieniężnej na wskazany przez nich cel społeczny, jeżeli doszło do zawinionego naruszenia prawa do umierania w spokoju i godności (art. 4 ust. 2 u.p.p.).

\section{Podsumowanie}

Planowanie opieki z wyprzedzeniem jest określeniem, które dotychczas nie było powszechnie rozpoznawane i stosowane $\mathrm{w}$ praktyce medycznej w Polsce, jednak osoby zaangażowane w opiekę nad pacjentami w różnym stopniu realizują podstawowe założenia ACP określone w definicji międzynarodowego zespołu ekspertów EAPC z 2017 roku. Również polskie prawo reguluje jedynie wybrane aspekty planowania opieki z wyprzedzeniem, pomijając rozwiązania dotyczące oświadczeń na przyszłość i pełnomocnika medycznego, co może powodować wątpliwości w zakresie możliwości ich zastosowania. W tym świetle realizacja procesu planowania opieki z wyprzedzeniem w pełnym zakresie wymaga wprowadzenia zmian w prawie polegających na określeniu szczegółowych zasad stosowania oświadczeń pro futuro i warunków ustanawiania pełnomocnika medycznego. Brak całościowej regulacji nie wyklucza jednak możliwości realizacji planowania opieki z wyprzedzeniem, a obowiązujące akty prawne odnoszące się do informowania pacjenta i uprawnionych osób, komunikacji w zespole terapeutycznym i zgody oraz sprzeciwu wobec udzielania świadczeń zdrowotnych, przewidują $w$ tym zakresie szereg obowiązków osób wykonujących zawody medyczne. Naruszenie tych przepisów może stanowić podstawę odpowiedzialności prawnej placówek ochrony zdrowia i osób w nich zatrudnionych, co uzasadnia wprowadzenie $w$ praktyce medycznej i przestrzeganie procedur w zakresie planowania opieki z wyprzedzeniem. 